\title{
Double Talk: Asturias's America in Cuculcán
}

iguel Angel Asturias's Cuculcán, a dramatic collage of color, sound, motion, and words, is his most overtly ethnographic play, and, as a product of his vanguardist years, it is also the most radically experimental. Cuculcán did not appear in print until 1948, ${ }^{2}$ but Asturias described the work in progress in a 1932 journalistic essay, "Las posibilidades de un teatro americano." 3 Although both Cuculcán and the Leyendas de Guatemala into which it was incorporated manifest Asturias's pursuit of new art forms that might evoke autochthonous New World experience, the play constructs a more complex version of America and its art than initially meets the spectator's eye.

Americanist aspirations constituted a significant thread in Latin American vanguardist activity of the 1920s and early 1930s. ${ }^{4}$ Manifestoes with an Americanist orientation often proclaimed with hyperbolic rhetoric the continent's energy, "ancestral" spirit, and radical newness as antidotes to European cultural exhaustion. With echoes from Whitman, Nietzsche, and Spengler and doses of Bergsonian elan vital, vanguardist documents forecast an energetic new American day, a potent new American species, and a radically new American art. ${ }^{5}$ Vanguardist creative works with an Americanist orientation such as Cuculcán often incorporated ethnographic materials from Latin America's non-Western cultures. ${ }^{6}$ Cultural critic James Clifford has documented the interaction between ethnography and art in Parisian post World War I vanguardist activity. $\mathrm{He}$ has also argued that, because of its decontextualized quality, ethnographic writing undertaken either by artists or by anthropologists is always allegorical. As Antônio Cândido pointed out with regard to Brazil, during the vanguard period Latin American writers claimed a privileged connection to the non-Western cultures that surrounded them. ${ }^{7}$ Although ethnographic material was employed in part to affirm the intrinsic worth of these cultures, it was also used allegorically to speak more broadly about the New World and its art. The international avant-gardes, in particular through primitivist modes, posed a connection between originality and origins, between artistic creativity and a notion of radical human or cultural beginnings. ${ }^{8}$ Latin American texts often recast this connection into New World contexts and portrayed America as a primeval world of ontological innocence and unprocessed experience retrievable from autochthonous sources, indigenous or imported. In this spirit, Cuculcán appears on the surface to reinforce the organicist myths of Latin America's cultural originality that, Roberto González Echevarría suggests, marked Latin American literature from the independence era until the emergence of the new narrative (41-43). ${ }^{9}$ But, at the same time, the play undermines primitivist representations of America by portraying a not-so-innocent New World as the site of creative deception and critique.

Asturias's 1932 article on Cuculcáninprogress underscored America's newness with a language typical of what Djelal Kadir has characterized as the obsession in Latin America's cultural imagination with "perpetually unfolding fictions that endlessly remake the New World anew" (6). Asturias was seeking a theatrical formula for what was "yet to be bom" as an American form of expression (477). ${ }^{10}$ His romantic description of the America to be embodied in such theatre was typical of the period in its telluric, organicist, and primitivist imagery:

El campo inmenso del trópico flagrante, la selva llena de sonidos, los mares olorosos a eternidad, las montañas 


\section{HISPANIA 75 SEPTEMBER 1992}

'cogidas de la mano a la hora del crepúsculo', los ríos impetuosos, los volcanes, que de jövenes se coronan de columnas de humo y de viejos de cabellos de nieves perpetuas, todo esto y cuanto más que no se dice, espera que se le lleve al teatro, no en forma de bambalina, en forma de soplo, de símbolo, de potencia verbal que, por fuerza de la evocación, llegue a crear con ellos un ambiente nuevo, el ambiente de la escena americana (477; my emphasis).

Like the emergent culture it was to represent, this theatre, would be childlike and "primitive," Asturias explained. Because America was "still playing," the new theatre exemplified by his dramatic piece would be like children's play and would, like children's word games, simply repeat the New World's fables without interpreting them (478). Only when it had outgrown this story-telling phase could America's literature move beyond repetition to interpretation and address concrete social problems. Cuculcán does indeed contain many elements of children's play as well as of traditional indigenous theatre, features Asturias had described in his essay, including color, dance, masks, verbal games, and repetitions. Even so, the play itself is not all play and constructs a world engaged in serious interpretation and critique.

Like the Leyendas de Guatemala, Cuculcain draws upon the Popol Vuh and the books of Chilam Balam. Described by Richard Callan as a chromatic ballet (124), the play enacts a series of encounters between the supreme plumedserpent god Cuculcán (likened in power to the sun) and the Guacamayo, the false god Vukub Cakix and a verbal trickster embodied in a parrot of many colors. ${ }^{11}$ The piece is organized into three sets of three alternating cortinas-yellow, red, and black. These colors correspond to stages in the sun's daily journey through the sky and are reflected in the colors of onstage curtains and the clothing and accoutrements of Cuculcán and his warriors. Other participants in the encounter between Cuculcán and the Guacamayo include Yaíand Chinchibirín. Yaí, a yellow flower sometimes linked to the moon in Mayan myth, has been destined since birth to mate with the supreme god and then be cast aside. Chinchibirín, a yellow warrior serving Cuculcán, loves Yai from afar.

Cuculcán incorporates these characters and others into a series of interlocking dialogues and displays of color, light, sound, and dance to enact a sustained debate on the nature of reality between Cuculcán and the Guacamayo. Declaring repeatedly "I am like the sun," Cuculcán affirms the palpable permanence of the world manifested in the cyclical recreation of each day
(54). The Guacamayo, or "Gran Saliva delEspejo" as he is called, harasses Cuculcán and his retinue with a repetitive "Acucuac, acucuac" and by endlessly asserting the transitory and illusory nature of reality, "a game of mirrors, a game of words" (87). "-Lo que se ve se ve y no es una ficción!" declares Cuculcan's warrior Chinchibirín(63)."Nada existe," the Guacamayo affirms, "todo es sueño en el espejismo inmóvil" (57). Although the play does not resolve this debate, the Guacamayo's version of reality prevails, as Yaí's union with the supreme god is portrayed as a fall from innocence that attests to the parrot's verbal power. ${ }^{12}$ Yai seeks to defend her illusion of love's permanence against her fate to be with Cuculcán for only one night, but, verbally seduced by the Guacamayo and converted to his views, she becomes like him, "words wrapped in words" (86). The parrot offers Yaí paradoxical counsel on love: "-Es eterno, pero no en el Palacio del Sol, en el Palacio de los Sentidos, donde, como todas las cosas, pasa, cambia!..." (87). The final dance between Cuculcán and Yai is performed as a fleeting encounter between the sun and the moon, a Mayan motif favored by Asturias.

Although the play's title names the supreme plumed-serpent god, the piece focuses more consistently on the Guacamayo who frequently steals the scene. Either in person or through the colors and the retinue that represent him, Cuculcán is always present. But the Guacamayo is far more active on stage as he disrupts the orderly universe that Cuculcán embodies. Visually, kinetically, and linguistically, the contrasts between the two figures are sharply drawn. The larger-than-life Cuculcán appears on stilts appropriate to his royal stature. The Guacamayo, according to stage directions, is "the size of a man" and appears initially "standing on the ground" (54). Cuculcán traverses the stage with "priest-like movements" (80), and his rhythmical, circular dance with Yaí emulates the periodic motion of heavenly bodies. By contrast, the Guacamayo's movements are playful, erratic, and clumsy, as he spins around, "entangled" and with "childlike joy" (55). Cuculcán's realm changes regularly with the time of day, but, at any given moment, this world is pervasively monochromatic: yellow, red, or black. The Guacamayo, on the other hand, a bird of many colors with plumage like a "Rainbow of Deception" (82), is multiple. As the Abuela de los Remiendos explains, guacamayos do not conform to a single type: "Hay guacamayos de cabeza colorada, pico amarillo muy ganchudo y 
vestido verde; otros de plumas amarillas resplandecientes; los llama de fuego, color de sangre coagulada y plumas azules en la cola, y los de bella emplumadura morada" (76).

But Cuculcán is above all a play about language, a sustained debate about an immutable correspondence between word and palpable world on the one hand and the duplicity and creative power of language on the other. Thus, the work's contrapuntual play of colors between a monochromatic Cuculcán and the chromatically volatile Guacamayo renders visually the profound contrast in the two beings' relationship to language. Linked to the cyclical recreation of each day, Cuculcán incarnates the power of an orderly universe. And although his similarity to the sun links Cuculcán with the ordering of time and space, the supreme god informs us that his power is impervious to the temporal and the contingent: "...mis rayos se convierten en brillantes avispas y vuelo a los panales, para luego seguir adelante, vestido del amarillo de mi imagen que sale del agua sin mojarse y de los panales sin quemarse" (55). In this spirit, Cuculcán's language affirms the scope of his own power and displays a respect for power itself. Thus, although the Guacamayo repeatedly tries to trick Cuculcán into a selfexalting identification with the sun ("eres el sol," the Guacamayo proclaims), the supreme god is careful always to compare himself to and never to equate himself with the sun: "I am like the Sun!" (54; my emphasis). ${ }^{13}$ This caution notwithstanding, Cuculcán's language, even when he speaks poetically, circumscribes his domain and describes the orderly world he rules:

En mis habitaciones de la mañana, bajo dosel de pájaros que vuelan y en sitial ordeñado del más puro oro de la tierra, me anudan en los negocios públicos, los encargados del Tesoro, de las Huertas, de los Graneros, al informarme de lo que pasa en mi señorio: de que si las nubes han hecho sus camas, de si los nidos viejos han sido cambiados, de si lo maduro no se ha podrido... (56).

Cuculcán lays claim to what he names through the frequent use of possessives: "-La Madre Ceiba amarilla es mi centro amarillo! -Amarillo es mi árbol, amarillo es mi camote, amarillos son mis pavos, el frijol de la espalda amarilla es mi frijol!"'(74). Here, Cuculcán's speech is characterized by simple declarative pronouncements and repetitions of the verb to be, reaffirming the stability of things as they are. Such statements often exploit the grammatical equation between subject noun and predicate noun $(a=b)$, a structure that implies a reliable equilibrium between word and world, for example "-El pedernal amarillo es la piedra de la mañana!" (74). ${ }^{14}$ Cuculcán's faithful warrior Chinchibirín employs a similar grammatical structure, in which $a$ equals $b$ so totally that the equation could easily be rendered as $a=a$. Thus Chinchibirín intones the redundant creed of Cuculcán's world view: "Lo que se ve se ve y no es una ficción!" (63; my emphasis).

The Guacamayo's response to this statement, “-Juguemos con las palabras!”(63), affirms the bird's playful approach to language and undermines the reliable connection between words and world proclaimed by Cuculcán. As a diviner, a storyteller, and a verbal gymnast, the Guacamayo emerges as the disruptive artist figure in Cuculcán's world. His irreverent attitude toward language lends support to Dorita Nouhaud's suggestion that the parrot incarnates the spirit of the vanguardist poet (252). ${ }^{15}$ As the "Gran Saliva del Espejo," the Guacamayo embodies linguistic deceit. His speech is described as "jerigonza," gibberish that twists the facts, and, in keeping with a Popol Vuh story of Vukub Cakix, he suffers from a twisted mouth and a painful toothache from having "chewed so many lies" (62). But though the Guacamayo may be an inveterate liar, the auditory, chromatic, and tactile metaphors and synesthesias that characterize his language emphasize the creative and critical power of his words. Thus, the "bird of enchantment" (76) speaks in a "jerigonza of colors" (56) with words like lies "clothed in precious stones" (79). The "rainbow of his voice" emerges from the Guacamayo's feathers, like the "rich plumage and perfect color" of his words (86). Most signficantly, the Guacamayo's "voice of fire" (78) constitutes an acute and acerbic critical force that needles, discomfits, and consumes from within those who hear it. "Tu voz," the yellow warriorChinchibirín tells the Guacamayo, "me llena el alma de cosquillas" (60). "-Tu hilera de colores," Yai tells the parrot of his language, "perforó mis orejas para engusanarme por dentro igual que el moco de donde salen mariposas!" (92).

If the pronouncements of Cuculcán and his followers affirm the stable nature of his domain ("lo que se ve se ve"), the Guacamayo's words assert the instability or even the absence of being. "Nothing exists," the parrot likes to quip (57), and he patiently explains to Chinchibirin that the afternoon is an illusion and that life itself is a "fictitious chain of days that leads to nothing" (92). The love Yai expects to find with Cuculcán is particularly vulnerable to life's fragility: “- 
Ay, mi acucuac, amarás esta noche lo que no es más que un engaño, producto de un juego de espejos, un juego de palabras, humores íntimos que se derramarán en realidad, en verdad, pero en un plano inferior al de la imagen adorada" (87). While Cuculcán's language shores up his own identity as a supreme god, the Guacamayo's words undercut in those who hear him any unified sense of being, fragmenting the simulacrum of a single self into many. Such is the parrot's powerful effect upon Yai whose hands are transformed into mirrors by his saliva:

YAI. - Mis manos son como mi ausencia. Por ellas me voy de mí, escapo de mí, de lo que son, de lo que pienso, de lo que siento, de lo que hago, para multiplicarme en vanas otras yo misma, que son iguales a mi y que no son sino una imagen de mi misma que no soy yo... - Muchas otras! -Tantas otras! (Viéndose en los espejos de sus manos.) Ésta de cara sonriente! -Ésta de cara muy seria! -Ésta que va a romper a llorar! - $i$ Ésta que parece pensativa y ésta que asoma indiferente como si nada le importara! (91)

In keeping with his parrot-like nature, the Guacamayo mimics Cuculcán's orderly syntax, the declarative affirmations that assert a stable word-reality relationship ("El pedemal amarillo es la piedra de la mañana"). But the parrot's mimicry is critical, as he appropriates this syntax in semantic paradoxes that assert the existence of nonexistence ("La tarde es una ficción" [64], "La vida es un engaño" [60]) or in typically vanguardist similes that construct a different order of things from that which prevails in Cuculcán's palace: "Las mujeres son vegetales" (58).

This play's contraposition through characters of contrary approaches to language is reinforced by staging and dramatic structure. On the one hand, the framing device of alternating series of three sets of curtains marks an unending cyclical repetition, as predictable as the sun's passage through the sky. On the other hand, the play's visual and verbal debates enclosed by this frame enact a volatile world (in which the "fruit run like rabbits") through the interplay of darkness, light, and color and the interweaving of voices, onomatopoetic natural and instrumental sounds, and dance-like actor movements. Thus, Cuculcán's orderly journey through the days is transformed by the Guacamayo's presence into a symphonic babble orchestrated by the poetic parrot's linguistic play:

(Ladridos de perros, cacareo de gallinas, truenos de tempestad, silbidos de serpientes, trinos de turpiales, guardabarrancas, cenzontles, se escuchan al irlos nombrando Guacamayo, asi como lloro de niños, risas de mujeres y para cerrar revuelo y palabrerío de multitud que pasa.) [57]

This cacophonic din invoked by the Guacamayo infects other characters who engage in similar verbal antics. The Popol Vuh figure Huaravarix, for example, composes nocturnal songs with word-plays similar in auditory effect to the tongue-twisters of vanguardist poets:

-El Cerbatenero de la Cerbatana de Sauco ha salido del Baúl de los Gigantes que en el fondo tiene arena y sobre la arena, aguarena y sobre la aguarena, agua honda y sobre el agua honda, agua queda, y sobre el agua queda, agua verde y sobre el agua verde, agua azul y sobre el agua azul, aguasol y sobre el aguasol, aguacielo! (69)

Even the powerful Cuculcán himself succumbs to the game of words in the final encounter with Yai as they twirl around in opposite directions: "-Y otra vez girasol de sol a sol, / sol, girasol y gira, girasol!" and, as he describes Yaí, "-Otra vez picaflor de flor en flor! / Recuerdo de la flor ¿qué fue de la flor?" (97).

Notwithstanding the carefully structured nine cortinas that frame it, the play is shaped by an alternating but continuing chain of verbal jousting, between the Guamayo and Cuculcán, the Guacamayo and Chinchibirín, Chinchibirín and Yaí, the Guacamayo and Yai, and Yaí and Cuculcán. Chinchibirín remarks that he yearns to "win the meet" with the Guacamayo (63). But winning in Cuculcán is based not so much upon converting others to one's views as upon the virtuosity of the performance and the power of the critique. The idea of a verbal match is reinforced by stage directions that portray Cuculcán's warriors as traders and their confrontation as an unending dance of exchange. The description of this scene points to the underlying structure of the play itself: "Entran y salen en formación interminable. ...empieza a anunciarse la batalla con gritos estridentes. Los guerreros rojos, por sus genuflexiones, más parecen tratantes que guerreros. Es un baile de ofertas y de réplicas" (80; my emphasis). This reference to the performance of a verbal exchange illuminates Asturias's attraction to drama for constructing an image of the New World as the site of linguistic prowess, a portrayal he had already intimated in the Leyendas's prose pieces. ${ }^{16}$ Performance theorist Richard Schechner has suggested that, while the Western mimetic tradition epitomized by nineteenth-century social drama focused attention on the written text, the avant-gardes revived ancient theatrical traditions by directing attention to the "doing aspects" of the script, or to theatre's performative substance (71). But in an 
actual performance, much of that "doing" involves words, and to talk about linguistic dexterity, Asturias chose a genre that in its execution constitutes a linguistic performance. In addition, by focusing spectator attention on the process of "offers" and "replies" that organizes the play, Cuculcán becomes a "nonorganic" work typical of the avant-gardes, to use Peter Bürger's term (68 ff.), and exposes its inner workings in order to talk about art. Cuculcán's ethnographic context focuses that discussion more specifically on issues of American art and culture.

The America portrayed by Cuculcán is a world of linguistic multiplicity in which verbal agility is valued not only for its creative force but also for its power to critique the fixed truths of a stable world. More specifically, like the multicolored Guacamayo that embodies its emergent forms of expression, the New World is the site of radical deception where things are not what they seem and where what you hear is as likely to confuse you as enlighten you. In this spirit of deception, Asturias's America in Cuculcán questions the primitive world of originary presences ascribed by European vanguardists to the non-Western cultures that fascinated them. It also belies the innocent, childlike, and primitive New World that Asturias himself had posed in the article that described Cuculcán in progress. Though the play draws upon Mayan cosmogony, the New World it portrays was never immutable or simple. Cuculcán himself explains that even when the world and its language were new, confusion, critique, and the Guacamayo were already on the scene:

Su voz. Habla oscuridad. De lejos es lindo su plumaje de alboroto de maíz dorado sobre el mar y la sangre. Todo estaba en las jícaras de la tiniebla revuelto, descompuesto, informe. El silencio rodeaba la vida. Era insufrible el silencio y los Creadores dejaron sus sandalias para significar que no estaban ausentes de los cielos. Sus sandalias o ecos. Pero el Guacamayo, jugando con las palabras, confundió los ecos, sandalias de los dioses. El Guacamayo con su lengua enredó a los dioses por los pies, al confudirles sus sandalias, al hacerles andar con los ecos del pie derecho en el pie izquierdo... (75).

There are striking points of contact between Cuculcán's America and Asturias's subsequent portrayal of the New World and its artists. With strong echoes from the polichromatic, linguistically agile parrot of the early play, Asturias suggested in his 1967 Nobel Prize acceptance speech, for example, that Latin American writers had created their own language, that their work constituted a "verbal feat" (158) and that their language itself was "chromatic," "musical," tactile, plural, and irreverent" (156). Similarly, the portrayal of Cuculcán's New World as a debate of offers and replies between traders is repeated in Asturias's 1959 description of a contemporary Guatemalan market, "Lo maya en los mercados guatemaltecos." Echoing Cuculcán's stage directions, this bargaining ballet exalts the virtuosity of the performance:

...las figuras de los mercaderes, hombres y mujeres que parece que no compraran ni vendieran, que no escogieran frente a cada puesto lo mejor, lo que más les gusta para adquirirlo, previo a un largo rosario de ofertas y demandas rechazadas, sino que ejecutaran una danza al compás del murmullo suave de las palabras que antojan el vuelo de millares de abejas sobre todas aquellas cabezas negras y cuerpos de vestidos coloridos propios de un ballet (256).

Interestingly, the comparison between the verbal jousting of the Guacamayo's world and a linguistic marketplace had already been made in Cuculcán by the warrior Chinchibirín: "Un mercado es como un Gran Guacamayo, todos hablan, todos ofrecen cosas de colores, todos engañan" (75).

But the salient quality of Asturias's America in Cuculcán, an idea that also persists in later writings, is the continent's ability to enact a Guacamayo-like deception before those who would know it. In the 1932 essay on an American theatre, Asturias expressed an ambivalent awareness of Europeans' exoticist New World expectations. Describing the discomfort of watching the performance of a South American play in Paris, he wrote: "y digo la pena porque la crítica fue unánime en el sentido de que nuestro autor había defraudado al público francés, que, ansioso de exotismo, buscaba un espectáculo de miga americana, y se encontraba una pieza de tipo francés del más mediocre" (477). On the surface it would appear that by writing an overtly ethnographic play, Asturias was merely giving a potential Parisian audience what it wanted and, in the process, was mimicking Western culture's (and the Parisian vanguards') primitivist representations of its others. But like the Guacamayo's response to Cuculcán's assertions of an orderly world, Asturias's New World portrayal performs a critical mimicry of its models to create an America where what you see is not so much what you really see as it is simply what you desire. Such a representation is reinforced by a 1969 Asturias essay "America, la engañadora," a piece that speaks extensively about a familiar parrot. Here Asturias recounted the Popol Vuh's portrayal of the guacamayo as a 
colorful verbal trickster and a god emerging prior to all other gods, but he also noted the parrot's subsequent role as America's first ambassador. Columbus, Asturias noted, had returned to the Old World with a parrot, not a hawk, on his arm, "diplomático que a su casaca de colores vivos une un hablar de enredijo propio del diálogo que va a seguir entre europeos y americanos" (343). Asturias characterized this deceptive dialogue as a self-protective tactic that helped America to save itself by "counterfeiting paradises" for the foreigners:

...el diálogo de la zalameria y el picotazo que caracteriza las relaciones entre europeos y americanos, el diálogo del que viste la mentira de sus colores para salvar la verdad de su mensaje, porque no de otra manera vamos a salvar los americanos lopropio, sinoengañando al europeo, fingiéndole montañas de oro al tamaño de su codicia, fuentes de juventud y paraísos perdidos (343).

n this spirit, Cuculcán's land of colors, abundance, magic, and innocent beings harbors a different America: a fragmented, deceptive world that undermines the fantasies of those who would know it. Echoing his own 1932 prediction that eventualy New World literature would go beyond its story-telling stage to engage in serious interpretation and critique, Asturias wrote in the 1968 essay "Tal y como somos: América fábula de fábulas:"

Se nos vuelve a soslayar, a no profundizar en nuestros problemas, salvo escasos grupos de estudiosos que se dan cuenta que para dilucidar aquel mundo hay que torcerle el cuello a la fábula. Es lo primero. ¿Quizá antipoetico? Pero no sólo de poesía vive el hombre. ...hay que exigir de los espíritus clarividentes de la epoca, una visión correcta de nuestras realidades. No más infundios, no más tergiversaciones. ... La fábula ha terminado y deben empezar a vernos tal y como somos" (341-42).

Twenty-two years after Asturias wrote this essay, it is difficult to ascertain the extent to which fables enveloping Latin America have been seriously discredited. But by portraying a linguistically duplicitous world resistant to uncontested truths and primitivist representations, Asturias's Cuculcán and its nettlesome Guacamayo were already engaging in that process.

\section{NOTES}

${ }^{1}$ A preliminary version of this piece was presented in Chicago at the December 1990 Annual Convention of the Modern Language Association.

${ }^{2}$ Asturias included Cuculcan and the prose piece "Los brujos de la tormenta primaveral" in the 1948 edition of the Leyendas de Guatemala, a work written in the 1920s and first published in 1930. The 1930 edition of the Leyendas, published by Madrid's Editorial Oriente, included "Guatemala," "Ahora que me acuerdo," "Leyenda del Cadejo," "Leyenda de la Tatuana," "Leyenda del Sombreron," and "Leyenda del tesoro del Lugar Florido." The 1948 expanded Spanish edition that included Cuculcán was published in Buenos Aires by Pleamar. Four more leyendas were published in the 1967 prose piece collection El espejo de Lida Sal (Mexico: Siglo XXI), and some recent editions of the expanded Leyendas have also incorporated these "Leyendas de las tablillas que cantan," "Leyenda de la máscara de cristal," "Leyenda de la campana difunta," and "Leyenda de matachines." Since I am interested in Cuculcán as a product of the vanguardia period, my own references to the Leyendas as an integral work do not take into account these last four pieces.

${ }^{3}$ Between 1924 and 1932, Asturias served as a Parisian correspondent for Guatemala's El Imparcial and wrote 440 articles. These have recently become accessible through Amos Segala's critical edition, Paris, 1924-1933. Periodismo y creación literaria.

${ }^{4}$ I use the term Latin American vanguardist activity or Latin American avant-gardes to designate the post World War I experimental artistic movements defined as the "vanguards," "vanguardism," or the "vanguardias" by Merlin Forster, Nelson Osorio, and Hugo Verani in their works on these movements. They constitute Latin America's recasting of the European avant-garde movements into its own cultural contexts. Peter Bürger employs the term "historical avant-gardes" in the European context to include pre and post World War artistic experiments primarily in Paris and Berlin. Forster's approximate and flexible chronological limits for Latin American vanguardism are 1920-1935; Osorio's, 1918-1930; and Verani's, 1916-1935.

${ }^{5}$ Cultural nationalism was widespread in Latin America's avant-gardes, evident in group activities, manifestoes, and the work of individual writers in the Caribbean, the Andean world, Chile, Brazil, Central America, and, to a lesser degree, in Mexico and Argentina. But nationalist concerns were often framed in broader Americanist contexts that are evident in manifestoes and critical articles of the period from Puerto Rico, Cuba, the Dominican Republic, Nicaragua, Peru, Ecuador, Uruguay, and Brazil. See the vanguardist manifesto and critical article anthologies by Osorio, Verani, and Gilberto Mendonça Teles for pieces by Puerto Rico's euforistas and noistas, by the Dominican Republic's postumistas, by Cuba's Grupo Minorista, by Brazil's Antropofagia group, and by Nicaragua's Anti-Academia Nicaragüense, as well as for manifestoes and articles from Cuba's Revista de Avance; Ecuador's Elan; Peru's Amauta and numerous Peruvian regional little magazines; Montevideo's La Pluma; and the Repertorio Americano published in San Jose, Costa Rica. The latter was not a vanguardist periodical, but it published pieces by groups and individuals associated with the movements.

${ }^{6}$ Other vanguardist ethnographic works include, for example, Alejo Carpentier's ;Ecue-Yamba-O!, Luis Cardoza y Aragón's Pequeña sinfonía del nuevo mundo, and Mário de Andrade's Macunaíma.

${ }^{7}$ Speaking of Brazil, Cândido wrote: "Ora, no Brazil as culturas primitivas se misturam à vida cotidiana ou são reminiscências ainda vivas de um passado recente. As terríveis ousadias de um Picasso, um Brancusi, um Max Jacob, um Tristan Tzara, eram, no fundo, mais coerentes com a nossa herança cultural do que com a deles" (121).

${ }^{8}$ For a discussion of the connection in vanguardist discourse between themes of originality and origins, see Rosalind Krauss's "The Originality of the Avant-Garde." 
${ }^{9}$ González Echevarría actually considers Carpentier's Los pasos perdidos (1953) to be the key work in undermining these myths: "The first work to reveal the critical substratum that had always denied the sense and coherence supposedly provided by the nature metaphor" (43).

${ }^{10}$ All translations from Spanish are my own.

"In the notes to Cuculcán, Asturias observes that there is a strong connection here beween the Kukulkán of the Mayas, the Gucumatz of the Quiches, and the Quetzalcohuatl of the Nahuas (115). The Guacamayo, "Gran Saliva del Espejo," is a recurring figure in Asturias's work. In the Leyendas de Guatemala, he appears in "Leyenda del tesoro del Lugar Florido" and "Los brujos de la tormenta primaveral."

${ }^{12}$ Eladia Leon Hill, in her study of "lo ancestral" in Asturias's work, suggests that Yaí ultimately embraces both points of view: the Guacamayo's affirmation of life's transitory quality and Cuculcán's embodiment of the eternal creation and recreation of the world (68-69). Although the dramatic world of Cuculcán does indeed incorporate the two views, if one focuses on the play's linguistic themes and qualities, the Guacamayo's views seem to prevail. More recent work on Asturias's Mayan sources, particularly in Hombres de maiz, has been done by René Prieto in a series of articles. See, for example, "The New American Idiom of Miguel Angel Asturias."

${ }^{13}$ As Asturias explains in the notes to Cuculcán, in the Popol Vuh, the Guacamayo's pride is his downfall, as he declares immodestly "I the sun, I the light, I the moon" (115).

${ }^{14}$ Asturias observes in the notes to Cuculcán that these references ("al pedernal amarillo, al pedemal rojo, al pedernal negro, etc.") recreate the descriptions in the books of Chilam Balam of Mayan conceptions of the world's four cardinal points (115).

${ }^{15}$ Nouhaud suggests this in the article "Quelle belle chose qu'un soleil d'aurore!" (252). A more extensive analysis of Cuculcán appears in her introduction to the critical edition of Tres de cuatro Soles, in which she relates the questions of orality, writing, and textuality in Cuculcán to the treatment of these issues in Tres de cuatro Soles.

${ }^{16}$ See, for example, "Guatemala," "Ahora que me acuerdo," and "Leyenda del tesoro del Lugar Florido."

\section{WORKS CITED}

Asturias, Miguel Angel. América, fábula de fábulas y otros ensayos. Ed. Richard Callan. Caracas: Monte Avila Editores, 1972.

"América, la engañadora." América, fábula de fábulas y otros ensayos. 343-47. Cuculcán. In Tres Obras. Leyendas de Guatemala-El Alhajadito-El Señor Presidente. Caracas: Biblioteca Ayacucho, 1976. 54-117.

. "Lo maya en los mercados guatemaltecos." América, fábula de fábulas y otros ensayos. 255-57.

. "La novela latinoamericana: testimonio de una época (conferencia Nobel)." América, fábula de fábulas y otros ensayos. 150-59.

Paris 1924-1933. Periodismo y creación

literaria. Ed. Amos Segala. Madrid and Paris: Colección Archivos, 1988.

"Las posibilidades de un teatro americano."
Paris 1924-1933. Periodismo y creación literaria.47779.

"Tal y como somos: América, fábula de fábulas." América, fábula de fábulas y otros ensayos. $340-42$.

Bürger, Peter. Theory of the Avant-Garde. Trans. Michael Shaw. Vol. 4 of Theory and History of Literature. Minneapolis: University of Minnesota Press, 1984.

Callan, Richard. Miguel Angel Asturias. New York: Twayne, 1970.

Cândido, Antônio. Literatura e sociedade: estudos de teoria e história literária. 6th ed. Sāo Paulo: Editora Nacional, 1980.

Clifford, James. "On Ethnographic Allegory." Writing Culture. The Poetics and Politics of Ethnography. Ed. by Clifford and George Marcus. Berkeley: University of California Press, 1986. 98-121.

."On Ethnographic Surrealism." The Predicament of Culture. Twentieth-Century Ethnography, Literature and Art. Cambridge: Harvard University Press, 1988. 117-51.

Forster, Merlin and K. David Jackson. Vanguardism in Latin American Literature-An Annotated Bibliographical Guide. Westport, CT.: Greenwood Press, 1990.

González Echevarría, Roberto. The Voice of the Masters Writing and Authority in Modern Latin American Literature. Austin: University of Texas Press, 1985.

Kadir, Djelal. Questing Fictions-Latin America's Family Romance. Vol. 32 of Theory and History of Literature. Minneapolis: University of Minnesota Press, 1986.

Krauss, Rosalind. "The Originality of the Avant-Garde." The Originality of the Avant-Garde and Other Modernist Myths. Cambridge: MIT Press, 1985. 151-70.

Leon Hill, Eladia. Miguel Angel Asturias. Lo ancestral en su obra literaria. New York: Eliseo Torrres, 1972.

Mendonça Teles, Gilberto. Vanguarda Européia e Modernismo Brasileiro. 7th ed. Petrópolis, R.J.: Editora Vozes, 1976.

Nouhaud, Dorita. Introduction. Tres de cuatro Soles. By Miguel Angel Asturias. Ed. Dorita Nouhaud. Mexico City: Fondo de Cultura Económica, 1977. xvxcv.

."Quelle belle chose qu'un soleil d'aurore!" Le personnage en question. Tolouse: Universite de Tolouse-Le Mirail, 1984. 251-59.

Osorio, Nelson T. Manifiestos, proclamas y polémicas de la vanguardia literaria en América Latina. Caracas: Biblioteca Ayacucho, 1988.

"Para una caracterización histórica del vanguardismo literario hispanoamericano." Revista Iberoamericana 47.114-115 (January-June 1981): 227-54.

Prieto, Rene. "The New American Idiom of Miguel Angel Asturias." Hispanic Review 56.2 (Spring 1988): 191208.

Schechner, Richard. "Drama, Script, Theater, and Performance." Performance Theory. 2nd ed. New York and London: Routledge, 1988. 68-105.

Verani, Hugo. Las vanguardias literarias en Hispanoamérica: Manifiestos, proclamas y otros escritos. Rome: Bulzoni Editore, 1986. 